\title{
Tomaž Onič
}

\section{Conference Report Artist and Citizen: 50 Years of Performing Pinter}

From April 12 to 14 , the University of Leeds, UK, hosted a conference to celebrate the $50^{\text {th }}$ anniversary of the first performance of a play by Harold Pinter. The central event of this threeday celebration was the ceremony during which Pinter was awarded an honorary degree from the University of Leeds for a lifetime's contribution to the arts.

Pinter (b. 1930) started his artistic career with poetry writing in the early 1950s and continued as a playwright later in the same decade. His first full-length play, The Birthday Party (1957), which is today one of Pinter's most frequently staged pieces, received mostly unfavourable reviews and closed after one week. But soon the predictions of Harold Hobson, who was one of the few critics defending Pinter from the beginning, came true: The Caretaker published in 1960 was an instant success. Followed by The Dwarfs (1960), The Collection (1961), The Lover (1962), The Homecoming (1964), Old Times (1970), Betrayal (1978) and others, it secured Pinter a firm place among the most important contemporary dramatists on the British theatrical scene. Today, the core of his literary heritage is represented by a total of twenty-nine plays - including the most recent ones Ashes to Ashes (1996) and Celebration (1999) - a number of shorter pieces for the stage, several screenplays and poetry.

Apart from being a playwright, a screenplay writer and a poet, Pinter has also been active as a director and an actor, often in his own plays. His most recent appearance on stage was in the role of Krapp in the production of Beckett's Krapp's Last Tape that took place in The Royal Court Theatre in October 2006. The then 76-year-old Pinter said he enjoyed the role - the more so because he had never been in a Beckett play before.

During his career, Pinter was awarded many literary and non-literary prizes for his literary achievements, most of them - including the most prestigious ones - in the last decade. Among the prominent awards are the Order of the British Empire, CBE (1966); the Shakespeare Prize, Hamburg (1970); the European Prize for Literature, Vienna (1973); The David Cohen British Literature Prize (1995); the Sunday Times Award for Literary Excellence (1997); the Companion of Honour for services to Literature, (2002); the Wilfred Owen Poetry Prize (2005); the Nobel Prize for Literature (2005); the European Theatre Prize (2006); and the Legion d'Honneur (2007). He has also been awarded honorary degrees from several British as well as foreign universities, the most recent being the one from the University of Leeds.

The conference was a pleasant combination of academic and artistic contributions. In addition to several academic papers by scholars from more than 10 countries, the participants saw three 
staged performances of Pinter's plays. For the first night, the organizer scheduled Monologue. Pinter's schoolmate and lifelong friend Henry Woolf kindly accepted the invitation to perform this piece written for him by Pinter in 1972. The dramatic power of the play merged beautifully with the real life situation in which one of the two men involved in the birth of this play was on stage and the other in the audience. The second day of the conference closed with an original theatrical work entitled Being Harold Pinter, brought to life by the Belarus Free Theatre. This group of young artists, who started their underground activity in 2005 as a means of resistance against President Lukashenko's political regime, gave a performance that combined several violent scenes from Pinter's plays that deal with the issues of human rights violation and political pressure on individuals. The performance was in Belarusian, but this did not affect its clear message projected through visual and other non-verbal means. The group and the piece were introduced by Pinter's fellow playwright Tom Stoppard, who had previously cooperated with the group and also helped the actors in acquiring travel documents. After the conclusion of panels on day three, we saw The Room. Again, it was Henry Woolf who in 1957 commissioned this first play by Pinter, thus possibly setting him on the playwriting track. As in the first production almost 50 years ago, which took place in a converted squash court at Bristol University, Woolf appeared in the role of Mr Kidd. The Room was an excellent event to close the conference.

Other artistic events included a poetry reading which took place during the honorary degree awarding ceremony; there were also showings of documentaries connected to Pinter, his works and his political beliefs in one way or another. A rich moment came with the opportunity to hear Voices, Pinter's most recent work with a strong musical component contributed by James Clarke.

Apart from Mark Taylor-Batty, conference organiser and associate editor of The Pinter Review, several distinguished Pinter scholars were present at the conference. Steven H. Gale, the founding president of the Harold Pinter Society and founding co-editor of The Pinter Review, gave a talk on highlights of Pinter's career intertwined with his personal life. Susan Hollis Merritt, bibliographical editor of The Pinter Review, took us back to her early encounters with Pinter's work and shared her impressions about her first meeting with the playwright himself. She also provided interesting details about studying the contents of boxes related to Pinter's literary heritage in the British Museum. Both plenary speakers, undoubtedly among the leading authorities in the field of Pinter studies, have studied Pinter's life and work for decades and have published numerous articles and monographs on the topic. There were two more guest speakers: Charles Grimes and Donald Freed. The latter was also invited to participate in the roundtable entitled Working with Harold Pinter together with James Clarke, Katie Read, Ian Rickson and Henry Woolf. A pleasant discussion on participants' experiences with what the title suggested was chaired by Pinter's biographer Michael Billington. It should also be mentioned that shortly before the conference, the revised edition of Billington's 1996 book The Life and Work of Harold Pinter, now entitled Harold Pinter, had just appeared in print and was available to conference participants - with the author's signature, of course.

The award ceremony was brief. In a short opening, a University spokesman mentioned Pinter's connection to Yorkshire cricket and his visit to a match in Leeds during World War II. Mark 
Taylor-Batty and students from the host university read some of Pinter's recent war poems. The high point of the event was conducted by the University Chancellor Lord Melvyn Bragg, who awarded the degree. After a short photo session, Pinter accompanied by his wife, the historic biographer Lady Antonia Fraser, left the Workshop Theatre.

Artist and Citizen: 50 Years of Performing Pinter was a memorable event, and after the conference dinner, which closed the social activities, it could be felt that all the participants left Leeds with pleasant sensations and impressions. Further details about the conference and some photographs are available at $\underline{h t t p: / / w w w . l e e d s . a c . u k / t h e a t r e / p i n t e r / i n d e x . h t m l .}$ 